\title{
壁面を伝う風による開き空ストッパー部品に作用する衝撃力の評価 Evaluation of Impact Force Caused by Wind Flowing along Wall in Stopper part of Swing-type Window
}

西江 学*1 森 孝男*2

Gaku NISHIE, Takao MORI

\begin{abstract}
SUMMARY
It is necessary for improving the safety of a swing-type window to evaluate the impact force caused by the wind flowing along a wall in the stopper part of the window. The strong wind test was performed in order to measure the impact force induced by a wind, and the characteristic of the wind energy and the impact force were clarified. The evaluation method of the impact force based on simple oscillation was proposed, and it is confirmed that the impact force by the proposed method is good agreement with the impact force by the drop weight test. It is considered that the proposed evaluation method is useful for the safety design of the swing-type window.
\end{abstract}

key words: Impact force, Wind flowing, Stopper part, Swing Type Window, Safety Design,

1.まえがき

開き空において，突風などにあおられてストッパ 一部品やガラスの破損，空の空扉（以下空と称す） の脱落などの事故が起きる場合がある。一般に空の 而風圧性能は空を閉じた時の外装材を想定した性能 評価が求められ，外装材の設計用風荷重は建築基準 法施行令や建築物荷重指針 ${ }^{1)}$ （日本建築学会）に定 められている。しかし，半開きの開き空が風にあお られた場合，開き空は任意の位置以上に開かないよ
うにストッパー部品が付いているが，空が急激にス トップした場合の衝撃的な荷重の評価は想定されて いない。このあおり風の危険性は経験的に知られて おり 2), 3),4), 安全性を確認するため暫定的な試験 方法が提案されているのが現状である。

室内から室外への風（以下室内風と称す）を対象 とした危険性は報告されており ${ }^{5)}$, 室内風に対する 空の安全性を確認する試験として, (社)日本サッシ 協会（以下サッシ協会と称す）は,「外開き空のあお

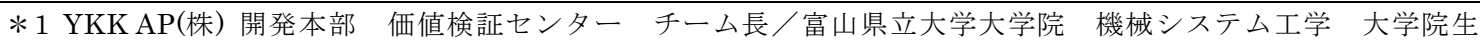
Research Engineer, YKK AP Inc. / Toyama Prefectural University

* 2 富山県立大学 教授

Professor, Toyama Prefectural University

(原稿受理年月日 : 2011 年 4 月 5 日，採用決定 : 2012 年 1 月 28 日) 


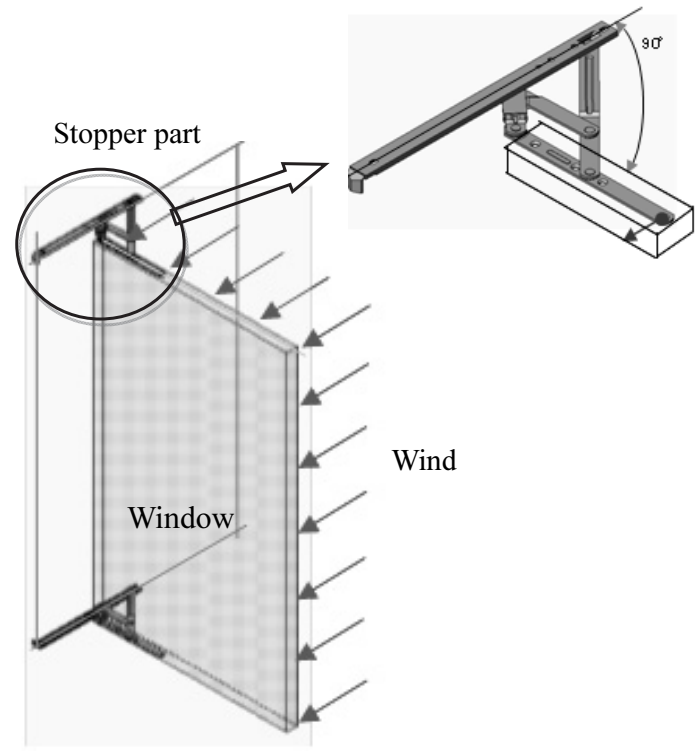

図 1 風を受けた時の開き空

(Swing-type Window)

り衝撃試験方法」を提案している ${ }^{6)}$ 。これは, 錘落 下により空に衝撃力を与える試験方法である。

一方，室内風以外に壁面に平行に伝う空の側面か らの風(以下側面風と称す)による危険性も知られて おり，落下事故の報告もある。図 1 に一般的な開き 空を示す。ストッパー部品は空の上下端に取り付け られ，空と壁面の空枠を連結している。開き空では 側面風によって空の運動エネルギーが生じ, ストッ パー部品が急激に停止した時の衝撃力となり破壊す ることが考えられる。また，ガラスも風圧力で割れ る前に，ストッパー部近傍で応力集中割れが多いた め，ストッパー部品が風から受ける衝撃力を把握す ることが求められている。しかし，側面風に関した 設計法や技術報告書および論文はなく，空の破損に 直結する開き空ストッパー部品の安全性を評価する 必要がある。

本研究の目的は, 側面風による開き空ストッパー 部品に作用する衝撃力を評価することである。その ため，まず，第 2 節ではベルヌイの定理から風の運 動エネルギー(以下, 本論文では風力エネルギーと称 す)を求めた。次に第 3 節では, 大型実風試験装置を 用いて実風を再現し，空周りの風の流れおよび空に 作用する風力に及ぼす風向き角度の影響を明らかに し, 第 4 節で，側面風が空に与える風力エネルギー
を実験的に導出した。そして，第 5 節で，空の回転 運動を 1 自由度系の運動方程式で近似し，側面風の 風力エネルギーから空のストッパー部品に生じる衝 撃力を評価することを試みた。

2. ストッパー部品に及ぼす風力エネルギー

ビルの形状や隅角部の風力係数に関する研究や設 計法は，種々報告されており ${ }^{7)}{ }^{8)}$ ，空が閉じている 場合には，壁面と同様に風力係数を用いて空に作用 する風圧を評価できると考えられる。本研究では壁 面に平行な側面風を対象としており，側面風が開い た空に作用する風力を直接求め, その風力と空の重 心位置の移動距離の積を風力エネルギーと考える。

側面風の風力エネルギーが空のストッパー部品の 変形エネルギーに推移することを想定すると ${ }^{9)}$, ス トッパー部品に生じる衝撃力が分かり，ストッパー 部品の安全設計が可能になる ${ }^{10)}$

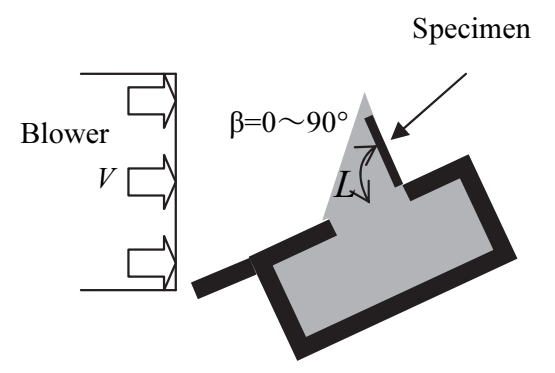

(a) 風洞試験(Blower test)

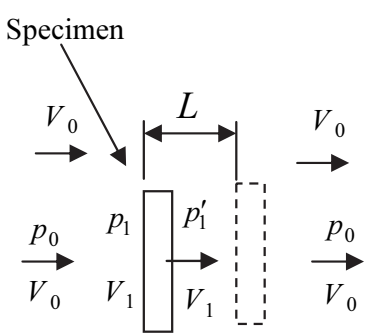

(b) 風エネルギーモデル(Wind energy model)

図 2 風洞試験による開き空風エネルギーモデル

( Blower test and wind energy model)

図 2(a)の矢印方向の風速 $V$ の風が，空に当たり 室内側に風が流入した瞬間に, 空全体に室内圧力 $P$ が加わると考えられる。このときベルヌイの定理は，

$$
p_{0}+\frac{1}{2} \rho V_{0}^{2}=p_{1}+\frac{1}{2} \rho V_{1}^{2}
$$


となる。ここで，式(1)の下付き添え字は，風が空に 衝突する直前を 0 , 衝突直後を 1 としている。 $p_{0}$ は 0 であり，風が空に遮られた時の $V_{1}$ を極限の 0 とする と，空の受ける圧力 $p_{1}$ は，

$$
p_{1}=\frac{1}{2} \rho V_{0}^{2}
$$

となる。ここで, $\rho$ は空気密度であり, 気温 $15^{\circ} \mathrm{C}$, 気圧 $1013 \mathrm{hPa}$ では $\rho=1.22 \mathrm{~kg} / \mathrm{m}^{3}$ である。

空に作用する風力エネルギー $K$ を風の運動エネ ルギーと考え, 風速を $V$, 空気の質量を $m$, 空の 重心の移動量を $L$, 空の面積を $A$ とする。図 2 (a) の円弧を図 2 (b) のように直線で表わすと，

$$
K=\frac{1}{2} m V^{2}=\frac{1}{2}\left(\rho A V \frac{L}{V}\right) V^{2}=\frac{1}{2} \rho A L V^{2}
$$

で求められ, 式 (3) は, 空に働く力と空の重心の移 動距離の積となっている。図2(a) において $L$ は, 空幅 $W$ の重心位置の移動距離 $L$ になるので, 回転中 心から重心位置は空幅 $W$ より $W / 2$ になり，空が 0 から $90^{\circ}$ まで開くと, 回転中心より重心位置の移動 距離 $L$ は,

$$
L=\frac{1}{4} \pi W
$$

となる。式 (3), (4) より風力エネルギーは

$$
K=\frac{1}{2} \rho A L V^{2}=\frac{1}{8} \pi \rho A W V^{2}
$$

で求められる。

\section{3. 空周りの風の流れおよび作用する風圧力 ${ }^{11}$}

\section{1 実験方法}

実験装置は図 3 に示寸 YKK AP（株）開発本部価 值検証センターの実風試験装置(エッフェル型)を使 用した。この試験装置は, 送風機の吹出し口 (ロ2500mm)から風下に家モデルが設置されている。 試験体を家モデルに取付け, 試験体がターンテーブ ルの中心になるようにし，ターンテーブルを回転す ることで風向き角度を変化させることができる。

この実風試験装置により，これまで確認すること が困難であった建物周りの風の流れを実験的に再現 できることとなり，側面風により開き空に作用する 風力を測定できる。そして，空が側面風から受ける
風力が最も大きくなる風向き角度を求めた。その角 度で, 風力と空の移動量の積を風力エネルギーとし て次節で求めた。

3. 2 風向き角度と側面風の風速の関係

図3のように, 風向き角度 $\alpha$ を $30^{\circ}$ から $90^{\circ}$ に変化 させ，側面風の風速を熱線風速計を用い，壁からの 距離 $L=120,300,500 \mathrm{~mm}$ 離孔た 3 点 $\mathrm{A}, \mathrm{B}, \mathrm{C}$ の位 置で測定した。開き空の一般的なサイズでは，風向 き角度が変わっても，図 4 のように壁面に平行に風 が流れると考えられる。そのため, 熱線風速計は壁 面に平行な風を測定できる角度にした。風圧と空面 積との積が風力になり, 最も風速が大きくなる角度 $\alpha$ が開き空にとって風力が最大となる。そのため, 設定風速 $V_{0}$ を送風機で一定に保ち, $5,10,15,20 \mathrm{~m} / \mathrm{s}$ の風をブロワから壁面に吹かせて，80 秒間に 2048 個の風速データを取り，その平均を側面風の風速と した。風向き角度 $\alpha=30^{\circ}, 45^{\circ}, 60^{\circ}, 75^{\circ}, 90^{\circ}$ での 側面風の風速 $V_{w}$ の変化を求めた。その関係を図 5 に 示す。図より，風向き角度 $60^{\circ}$ から $75^{\circ}$ 付近で壁を沿 う風速は最大となり $V_{0}$ と $V_{w}$ はほぼ等しくなった。 したがって, 側面風の風速として, 初期の風速 $V_{0}$ を 用いる。図 6 に, 風向き角度 $60^{\circ}$ と $75^{\circ}$ の時の, 壁面 からの距離と側面風の風速の関係を示す。壁面から 近い位置の風速が若干速いが，距離の差はほとんど なく, 風向き角度 $60^{\circ}$ と $75^{\circ}$ では, 壁面にほぼ平行に 風が流れている。

\section{Hot Wire Anemometer Set Point}

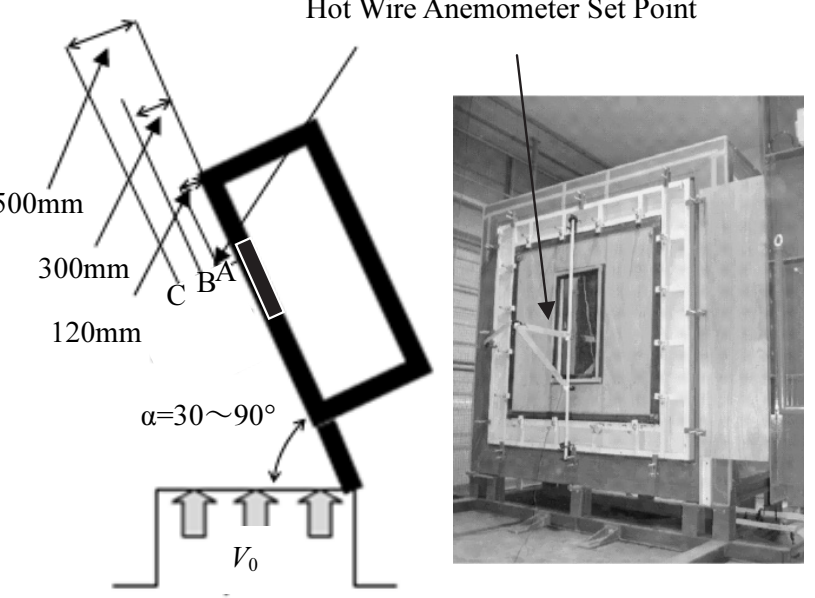

$\begin{array}{ll}\text { (a) 立面図(Top view) } & \text { (b) 側面図(Side view) }\end{array}$

図 3 側面風測定図 $\left(\alpha=75^{\circ}, \beta=0^{\circ}\right)$

(Measure of wind velocity at $\alpha=75^{\circ}, \beta=0^{\circ}$ ) 


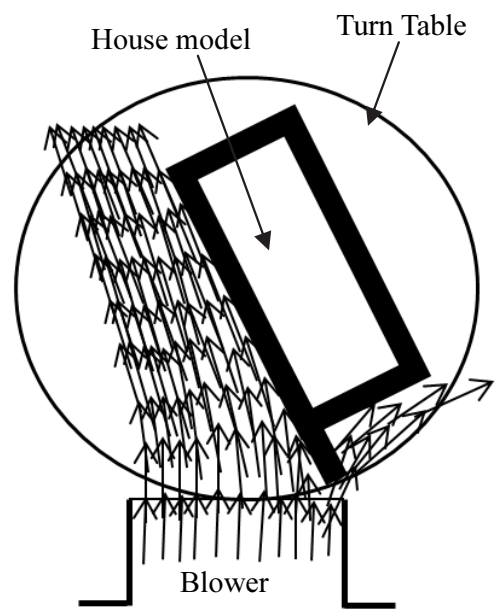

図 4 側面風モデル図(風洞試験)

(Blower test and wind direction model)

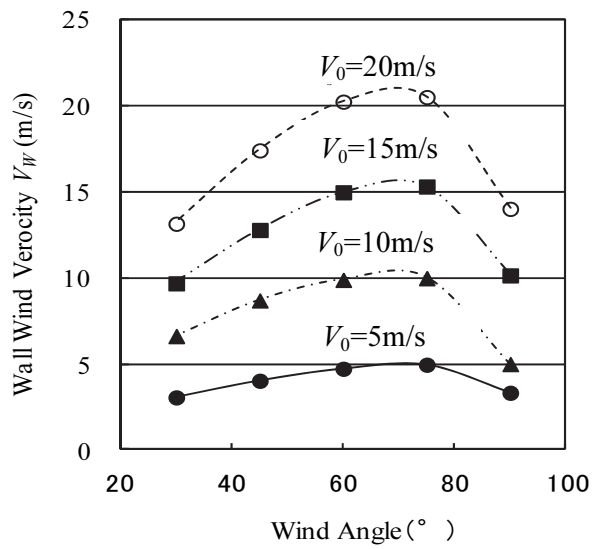

図 5 風速一風向き角度図

(Wind Velocity- Wind angle curve)
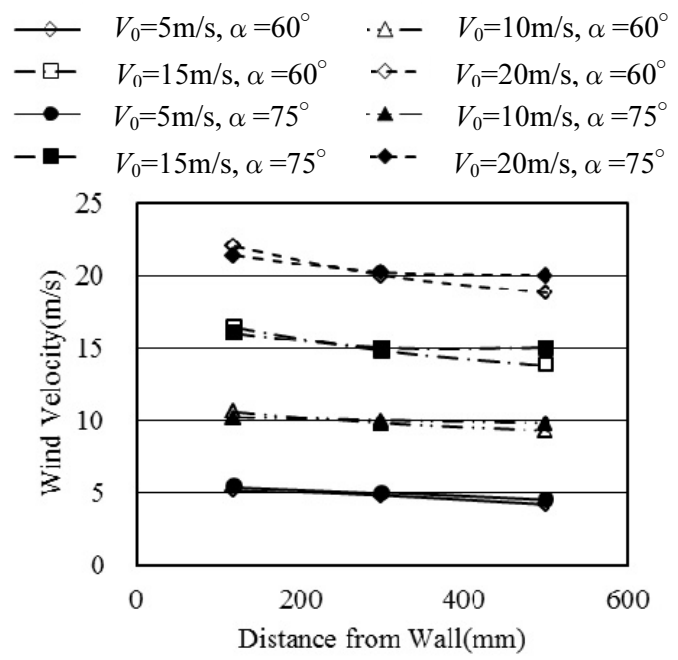

図 6 風速と壁からの距離の関係図

(Wind Velocity-Distance from Wall curve)
3. 3 風向き角度と空が受ける風力の関係

本研究の対象とする空では, ストッパー部品に より，空が $90^{\circ}$ 以上に開かないようになっている。 空が $90^{\circ}$ 開いた状態で，空に作用する風力を測定す るため, 図 7 のようにストッパー部品にひずみゲー ジを張り，引張りひずみを測定した。

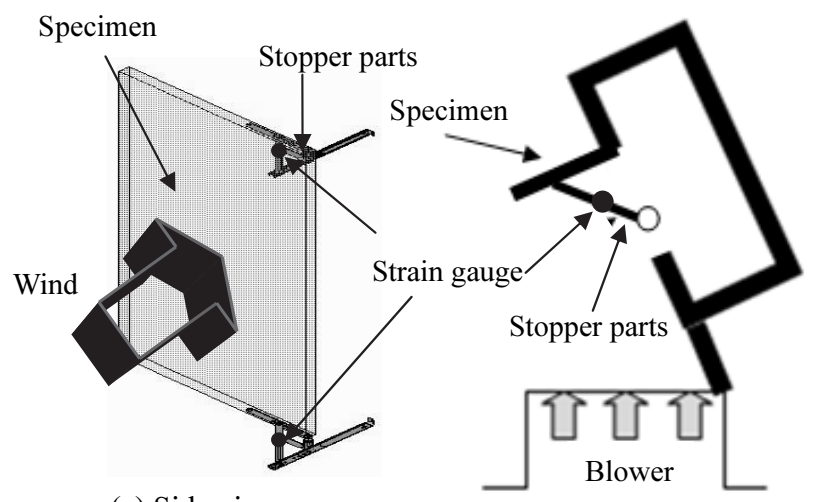

(a) Side view

(b) Top view

図 7 ストッパー部品ひずみ測定図 $\left(\alpha=45^{\circ}, \beta=90^{\circ}\right)$

(Measure of stopper part strain at $\alpha=45^{\circ}, \beta=90^{\circ}$ )

図 5 の空が閉じた時の側面風の風速実験結果から, 本試験は風向き角度 $60 \sim 75^{\circ}$ の間で最大の力が発生 寸ると考え, 空が開いた状態で, 風向き角度 $60 \sim 90^{\circ}$ において 5 こことに変化させて，ストッパー部品に生 じるひずみを測定した。その結果を図 8 に示す。ス トッパー部品のひずみの最大は風向き角度 $60 \sim 80^{\circ}$ でほぼ同じ値になった。よって, 風力についても図 5 の壁面風速の測定結果と同様な結果となった。

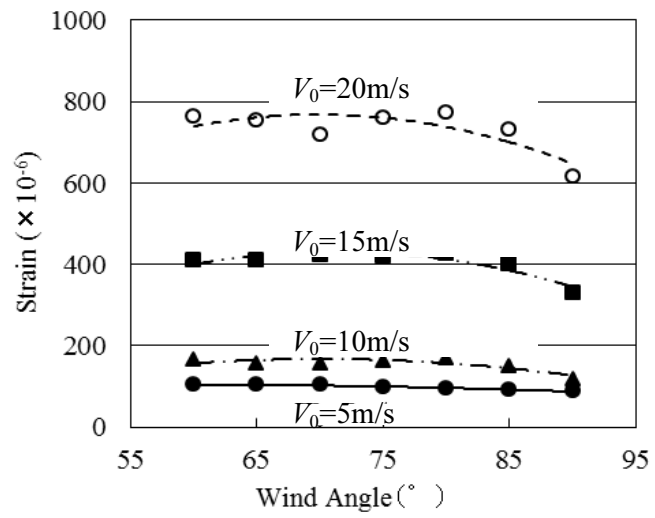

図 8 ストッパー部品ひずみ-風向き角度図 (Stopper part Stain - Wind Angle curve) 


\section{4 流体解析による検討}

空が閉じた時の側面風の風速と，また，空を $90^{\circ}$ に開いた時の空に働く力の, 風向き角度の影響を検 討したが，風向き角度 60 ～ $80^{\circ}$ でほとんど変わらな かった。ここでは, 空周辺の風の流れを詳細に確認 するため, 流体解析 (以下 CFD 解析と称す) を行っ た。CFD 解析には汎用流体解析ソフト「STAR-CD v 3.2」を用いて, 速度ベクトルと圧力分布で気流の 評価を行った。CFD 解析は 3 次元モデルで行い, 計 測室, 吹出し口, 家モデルを作成した。境界条件は, 計測室, 家モデルの壁面は固定壁条件を, 空気吹き 出し口は一様流条件, 空気出口は自由流出条件を設 定した。また，乱流モデルは「標準 $\mathrm{k}-\varepsilon$ モデル」 を使用し, 差分スキームには運動量方程式, 乱流エ ネルギー及び散逸率の輸送方程式 $(\mathrm{k}, \varepsilon)$ の移流項 各々に, 風上差分を適用した。空気の物性は, 密度 $\rho=1.205 \mathrm{~kg} / \mathrm{m}^{3}$ ， 粘性係数 $\mu=1.81 \times 10^{-5} \mathrm{~Pa} \cdot \mathrm{s}$, 比熱 $C v=1006 \mathrm{~J} / \mathrm{kg} \cdot \mathrm{K}$, 熱伝導率 $\lambda=0.02637 \mathrm{~W} /(\mathrm{m} \cdot \mathrm{k})$ とした。 図 9 は CFD 解析を実施した風向き角度 $65^{\circ}$ の速度べ クトルを示す。図より，空に圧力が発生し，それを 避けるように, 空より外に空気が流れていることや, 室内側にわずかに空気が入ることが確認できた。 図 10 は, 空が開いた状態で空に加わる力の最大值を 導出するため, 風向き角度 $50 \sim 90^{\circ}$ において $5^{\circ}$ ス

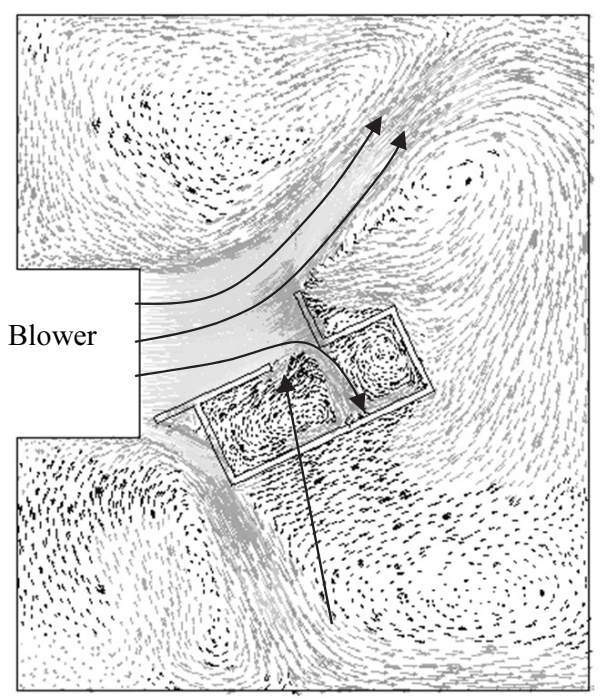

図 $9 \mathrm{CFD}$ 解析結果図 $\left(\alpha=65^{\circ} \beta=90^{\circ}\right)$

(Result of CFD analysis at $\alpha=65^{\circ} \beta=90^{\circ}$ )

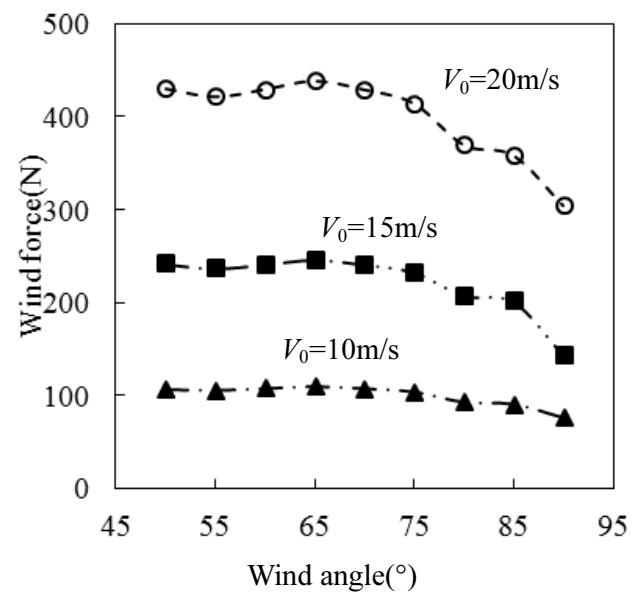

図 10 風力-風向き角度図 (CFD 解析)

(Wind force-Wind angle curve : CFD analysis) テップで空に働く力を CFD 解析結果で得られた空 に作用する圧力から計算した結果である。

図 8 に示すストッパー部品のひずみは, 風力に比例 する。したがって, CFD 解析と実験結果の双方とも, 風力が最大となる風向き角度が $60^{\circ}$ から $75^{\circ}$ となり 一致した。よって, CFD 解析による風力の最大值が 風向き角度 $65^{\circ}$ であったので, 側面風力エネルギー の測定を風向き角度 $65^{\circ}$ で行う。

\section{5 家モデル内部空間の影響}

開き空の室内側の空間が閉じている場合，時間が 経過すれば室内圧力が一定になるが，初期段階では 一定ではない。圧力が一定になるまでの時間が短時 間であれば，空には室内圧力がほぼ一定に作用する ことになる。そのため一定の圧力になるまでの時間 について検討する。

図 9 の結果より, 室内側に入る風の流れがあり, 室内に空気が入る量は内外の圧力差より次式で与え られる。

$$
\begin{aligned}
& Q= C A \sqrt{\frac{2 \Delta p}{\rho}} \\
& Q: \text { 漏気量 }\left(\mathrm{m}^{3} / \mathrm{s}\right) \\
& C: \text { 流量係数 } \\
& A: \text { 漏気面積 }\left(\mathrm{m}^{2}\right) \\
& \Delta p: \text { 圧力差 }\left(\mathrm{N} / \mathrm{m}^{2}\right) \\
& \rho: \text { 空気密度 } 1.22\left(\mathrm{~kg} / \mathrm{m}^{3}\right)
\end{aligned}
$$




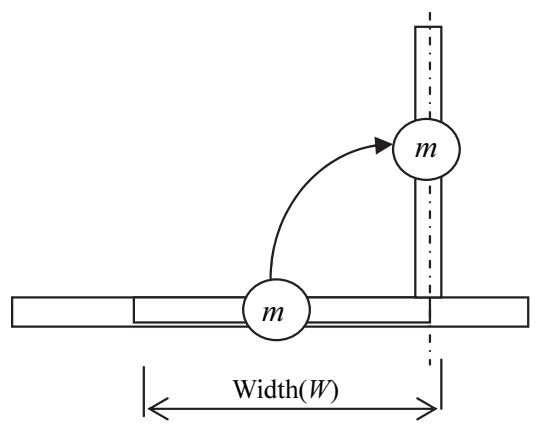

図 11 開き空(全閉 $0^{\circ} \sim$ 全開 $90^{\circ}$ ) の軌跡

(Swing type window follow the tracks 0 to $90^{\circ}$ )

西沢らの研究によると,「矩形開口の流量係数と流 入角度」 ${ }^{12)}$ では, 風向き角度 $65^{\circ}$ では流量係数は 0.35 になる。よって, 実験で行った幅 $3.3 \mathrm{~m} \times$ 奥行き $1.4 \mathrm{~m} \times$ 高さ $3 \mathrm{~m}$ （容量 $13.86 \mathrm{~m}^{3}$ )の家モデルで，室内圧が風 速 $20 \mathrm{~m} / \mathrm{s}$ 相当の内外圧力差 $245 \mathrm{~N} / \mathrm{m}^{2}$ になる状態を仮 定すると, 容積の 0.0024 倍の $0.034 \mathrm{~m}^{3}$ の空気量の侵 入が必要であり，空サイズが $W=800 \mathrm{~mm}$,

$H=1200 \mathrm{~mm}$ で, 流量係数 0.35 として, $0.034 \mathrm{~m}^{3}$ の空 気の塊が仮に一気に侵入したとすれば 0.005 秒で風 圧相当の圧力になる。

次に空が開く時間について検討する。図 11 のよう に空幅 $W$ の中心に式(6)の圧力差に基づく力 $F$ は, 開閉力を $20 \mathrm{~N}$ とすれば,

$$
F=\frac{1}{16} A V_{0}^{2} \times g-20
$$

となる。質量 $m$ の空を加速度 $a$ で回転させる力 $F$ は,

$$
F=m a
$$

である。したがって, 加速度 $a$

$$
a=\left(\frac{1}{16} A V_{0}^{2} \times g-20\right) /\left(\frac{1}{16} A V_{0}^{2}+m\right)
$$

となる。

開き始めの 0 〜 90までの重心の移動距離 $L$ になり， 開く時間を $T$ とすると

$$
\begin{aligned}
& \frac{1}{2} a T^{2}=\frac{1}{4} W \pi \\
& T=\sqrt{\frac{1}{2} \frac{W \pi}{a}}
\end{aligned}
$$

になる。
式(9), (10)に, 質量 $m=20 \mathrm{~kg}$, 空幅 $W=0.8 \mathrm{~m}$, 障子 面積 $A=0.96 \mathrm{~m}^{2}$ (空高さ $H=1.2 \mathrm{~m}$ )を代入すると, 空が開 く時間 $T$ は 0.5 秒になる。よって, 室内圧が風速相 当圧力になる時間が上記より 0.005 秒とすれば非常 に時間が短いので家モデル内部空間の影響はない。 室内容積が 10 倍に増えたとしても, 空に働く圧力に ほとんど影響がなく，本実験で求める風力エネルギ 一に，閉じた空間の容量の影響は少ないと考える。 仮に大空間でも，空に働く圧力は容積が小さい方が 大きく, 設計上安全側になるので問題ないと考える。

4. 風力エネルギー測定実験 ${ }^{11)}$

4.1 風力エネルギーの測定

式(5)に示すように，空に作用する風のエネルギー は空寸法の影響を受ける。一般的な空の寸法は幅 500mm〜900mm であり, 高さ $800 \mathrm{~mm} \sim 1800 \mathrm{~mm}$ であ ることを考慮し，試験を行う空の寸法を表 1 のよう にした。

表1 試験体サイズ表 (Specimen condition)

\begin{tabular}{|c|c|c|}
\hline $\begin{array}{c}\text { Specimen } \\
\text { (No.) }\end{array}$ & $\begin{array}{c}\text { Width } \\
(\mathrm{mm})\end{array}$ & $\begin{array}{c}\text { Height } \\
(\mathrm{mm})\end{array}$ \\
\hline 1 & \multirow{2}{*}{900} & 1800 \\
\cline { 1 - 1 } 2 & & 1300 \\
\hline 3 & 700 & \multirow{2}{*}{800} \\
\hline 4 & 500 & \\
\hline 5 & &
\end{tabular}

Wire and Load Cell

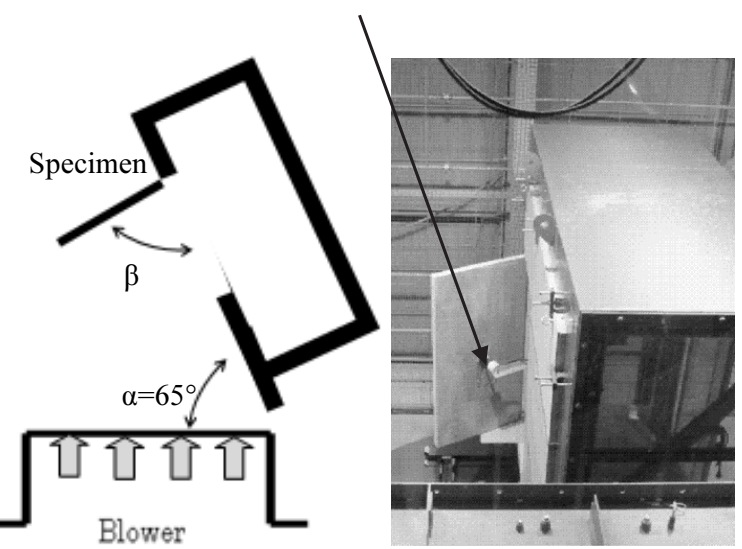

図 12 風力の測定図 (Measurement of wind force) 


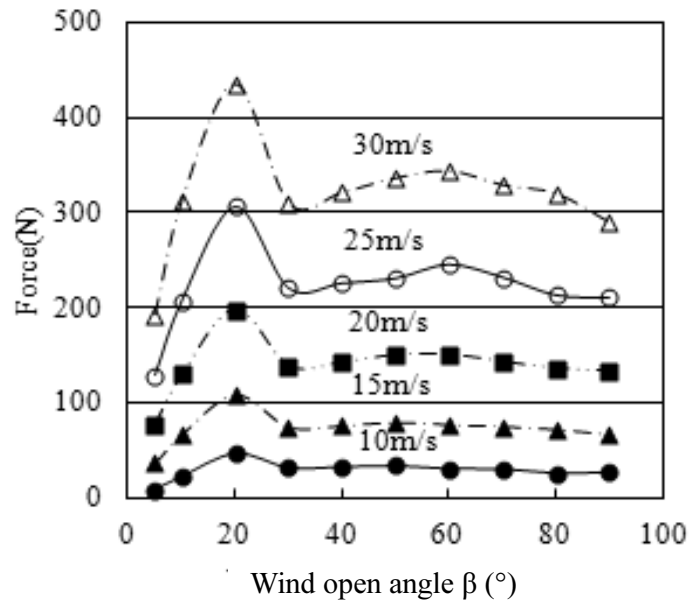

図 13 風力一開き角度 $\beta$ 図 $\left(\alpha=65^{\circ}\right.$, 試験体 No.3)

( Wind Force - Window open $\beta$ curve : $\alpha=65^{\circ}$, Specimen

No.3: $\mathrm{W}=900, \mathrm{H}=800$ )

図 13 に風力と空の開き角度の関係を示す。図 12 のように，風向き角度 $\alpha$ を $65^{\circ}$ にして，空の開き角 度 $\beta=5 \sim 90^{\circ} \quad\left(10 \sim 90^{\circ}\right.$ では $10^{\circ}$ ごと）で, 空全体 に作用する風力を，戸の中心に設置したワイヤーを 介してロードセルで測定した。初期の風速 $V_{0}$ は $10 \mathrm{~m} / \mathrm{s}$ から $30 \mathrm{~m} / \mathrm{s}$ まで $5 \mathrm{~m} / \mathrm{s}$ おきに変化させた。

図より，異なる風速でも，開き角度 50 では風力は ほとんど発生していないが，開き角度 $10^{\circ}$ から $20^{\circ}$ で風力は大きくなり，30〜90にかけてほぼ一定の 值となった。本研究では, 図 13 の荷重と各角度間で

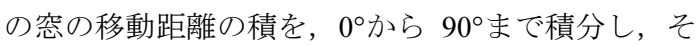
の值を側面風が空に与える風力エネルギーとした。

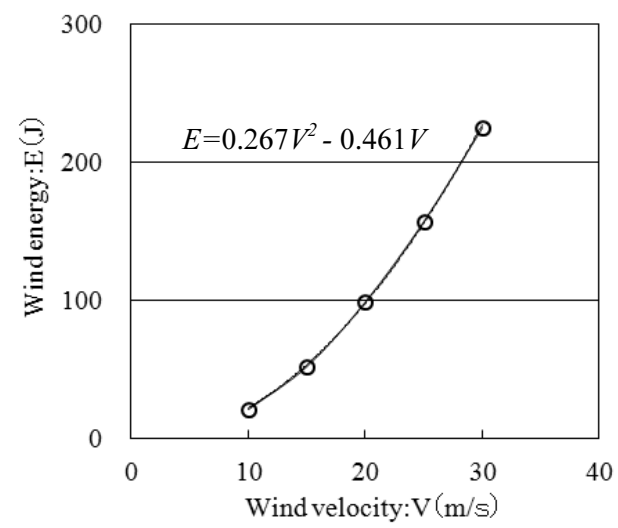

図 14 風エネルギー-風速図(試験体 No.3)

(Wind energy and wind velocity curve Specimen No.3: $\mathrm{W}=900, \mathrm{H}=800$ )

\section{2 風力エネルギーの評価}

図14は，試験体No.3の風力エネルギーを示す。風 カエネルギーは速度の2次式で近似でき, 風力エネル ギーを $E$ ，風の速度を $V_{0}$ とすると，

$$
E=0.27 \mathrm{~V}^{2}-0.46 \mathrm{~V}
$$

となる。

図 15 は, 高さが同一で幅の異なる試験体 No.3, 4, 5 の風力エネルギーを, 試験体 No.3 の風力エネルギ 一に対する比 $R_{W}$ とし， $R_{W}$ と空幅 $W(\mathrm{~mm})$ の関係を 示したものである。

$$
R_{W}=0.0018 W-0.63
$$

となる。

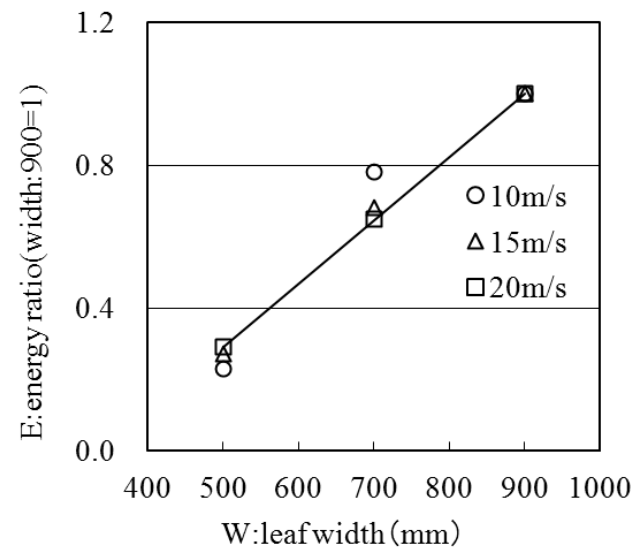

図 15 試験体 No.3〜 5 風エネルギーと空幅の関係

(Wind energy ratio to leaf height

Specimen No.3 5: $\mathrm{W}=900 \sim 500$ )

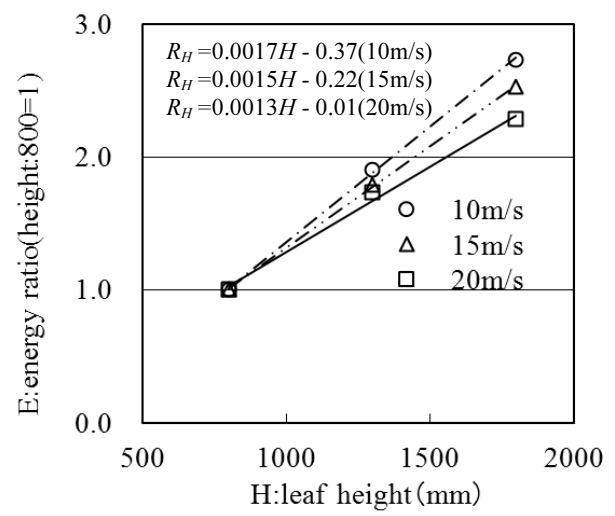

図 16 試験体 No.1〜3 風エネルギーと空幅の関係

(Wind energy ratio to leaf height

Specimen No.1 3: H=1800 800) 
図 16 は，基準となる試験体 No.3 1 とした，風 カエネルギー比 $R_{H}$ と空高さ $H(\mathrm{~mm})$ の関係を示し, $R_{H}$ は風速により異なり,

$$
R_{H}=a H+b
$$

と表し， $a, b$ を風速 $V$ の関数で近似すると

$$
\begin{aligned}
& a=-3.6 \times 10^{-5} V+0.0021 \\
& b=0.033 V-0.7
\end{aligned}
$$

となった。

この結果より風力エネルギー $E$ を, 試験体 No.3 の風力エネルギー $E_{0}$ を基準とし, 風速 $V$, 空 幅 $W$, 空高さ $H$ の関数として実験式を表す と,

$$
\begin{aligned}
E & =E_{0} \times R_{W} \times R_{H} \\
& =\left(0.27 V^{2}-0.46 V\right) \\
& \times(0.0018 W-0.63) \\
& \times\left\{\left(-3.6 \times 10^{-5} V+0.0021\right) H\right. \\
& +(0.033 V-0.7)\}
\end{aligned}
$$

となる。

4.3 ベルヌイの定理による風力エネルギーの評価 ベルヌイの定理から求めた式(5)で算出される風 力エネルギーと, 実験で求めた式(12)で算出される 風力エネルギーの比較を行い, ベルヌイ式で風力エ ネルギーを求めることの妥当性を検討した。その結 果を図 17 図 19 に示实 17 は試験体 No.1

$(W=900 \mathrm{~mm}, H=1800 \mathrm{~mm})$ の結果である。図 18 は 試験体 No.3 ( $W=700 \mathrm{~mm}, H=800 \mathrm{~mm})$ の結果である。 図 19 は，試験体 No.5（ $W=500 \mathrm{~mm}, H=800 \mathrm{~mm} ）$ の 結果である。ベルヌイ理論式による風力エネルギー は，あおり風で最も事故が起こっている風速 $20 \mathrm{~m} / \mathrm{s}$ で, 試験体 No.1 では実験式の 1.2 倍, 試験体 No.3 では 1.4 倍, 試験体 No.5 では 1.6 倍となった。何れ の試験体でも, ベルヌイ理論式(5)による風力エネル ギーは，実験式(12)による風力エネルギーより大き い結果になった。空サイズが大きい方が，実験式に 対するベルヌイ理論式の比が小さくなり，その值が 1 に近付いている。図 9 に示す CFD 解析結果から, 風の流れは図中の矢印のようになり, 空の端部では 風の流れがあり，空の中央部より風圧が減少してい ることが推測できる。空サイズが大きくなるほど端

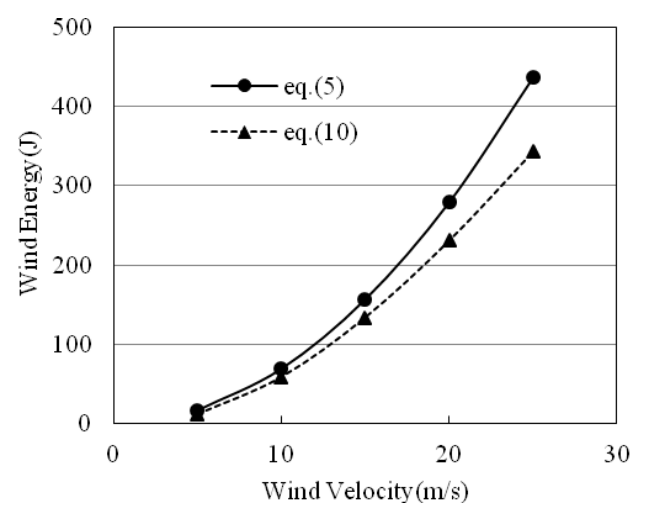

図 17 風エネルギー-風速図 (試験体 No.1)

(Wind energy -Wind Velocity curve

Specimen No.1: $\mathrm{W}=900, \mathrm{H}=1800$ )

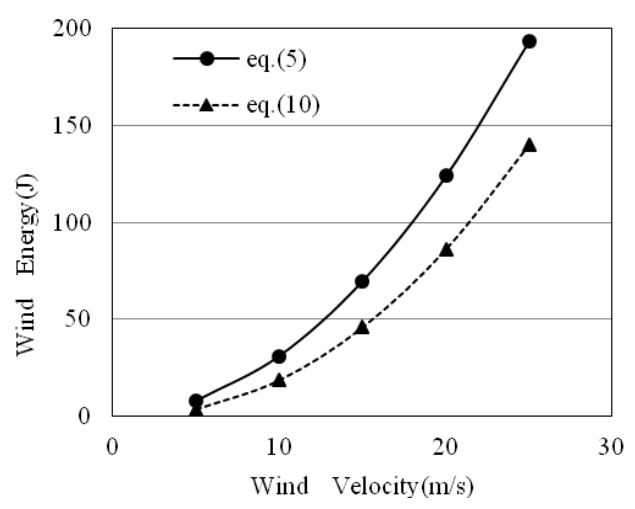

図 18 風エネルギー-風速図(試験体 No.3)

(Wind energy -Wind Velocity curve

Specimlen No.3: $\mathrm{W}=900, \mathrm{H}=800$ )

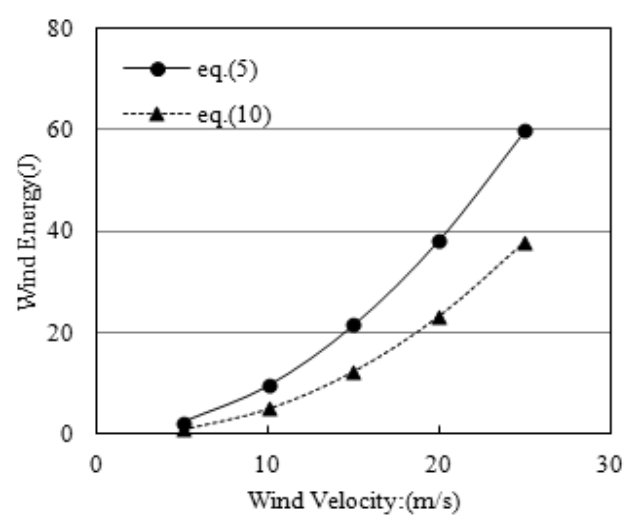

困 19 風エネルギー-風速図(試験体 No.5)

(Wind energy -Wind Velocity curve Specimen No.5: $\mathrm{W}=500, \mathrm{H}=900$ ) 
部の影響は小さくなるので, 実験式に対するベルヌ イ理論式の比が 1 に近付くと推測できる。いずれに しても，ベルヌイ理論式は実験式より大きな值とな るので, ベルヌイ理論式基づく風力エネルギーを用 いれば，安全側に設計できる。

\section{5. ストッパー部品に作用する衝撃力の評価}

第 4 節において, 空に働く風力エネルギーを, 風 速に応じて導出できた。一方, ストッパー部品を設 計するには, ストッパー部品に㗢く衝撃力を, 風速 に応じて求める必要がある。ここでは, 開き空の運 動をばね-マスモデル(1 自由度振動系)で近似し, ス トッパー部品に作用する衝撃力の評価する。そして, 風力エネルギーと同一のエネルギーを与える鍾落下 試験を行い，ストッパー部品に生じる衝撃力を測定 し，その妥当性を検討する。

\section{1 ばね-マスモデルによる衝撃力の評価 ${ }^{13)}$, 14)}

質量 $M$ の空がストッパー部品で停止するとき, 弾 性限度内で空とストッパー部品を 1 質量系単振動の 運動方程式で近似すると, 運動方程式は次式で与え られる。

$$
M \frac{d^{2} X}{d t^{2}}+k X=0
$$

ここで， $k$ はストッパー部品をばねと考えたときの ばね定数である。ばねの伸びが $X_{0}$ であるとき， ス トッパー部品が有するエネルギー $E$ は,

$$
E=\frac{1}{2} k X_{0}^{2}
$$

となる。

したがって, 静止距離 $X_{0}$ は,

$$
X_{0}=\sqrt{2 E / k}
$$

となる。よって, ストッパー部品に生じる荷重 $F$ は,

$$
F=k X_{0}=\sqrt{2 k E}
$$

となる。以上により，式(16)に，風力エネルギー実 験式(12)を代入することにより，種々の空の寸法や 風速に対するストッパー部品の衝撃力が求まる。

\section{2 衝撃力の評価方法の妥当性の検討}

前節で述べた 1 質量系単振動の運動方程式による 衝撃力の評価式の妥当性を確認するため, 図 20(a)
に示す錘落下試験を行った。このとき, 錘の位置エ ネルギーを風力エネルギーと同一と成るようにした。 本試験は，空が閉じた状態から，錘落下エネルギー により空が開き，そして空が開ききったときストッ パー部品に衝撃力を与える。空が受けるエネルギー $E$ は, 錘の質量を $M$, ストッパー部品の摩擦力を $f$, 落下距離を $H$ とすると,

$$
E=(M g-f) \times H
$$

となり，式(16)より，荷重 $F$ は，

$$
F=\sqrt{2 k(M g-f) \times H}
$$

となる。式(18)で荷重 $F$ を求めるには, ストッパ

一部品のばね定数 $k$ と摩擦力 $f$ を求める必要がある。

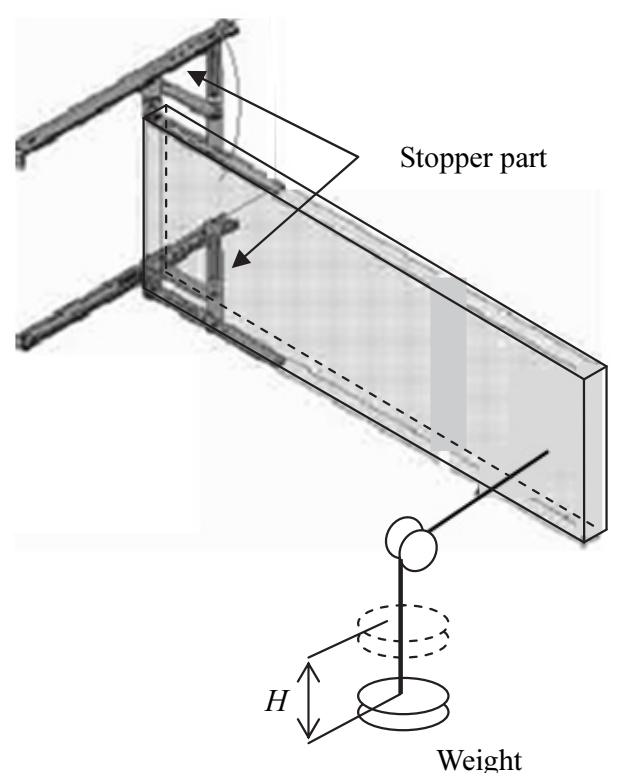

(a) Weight drop test

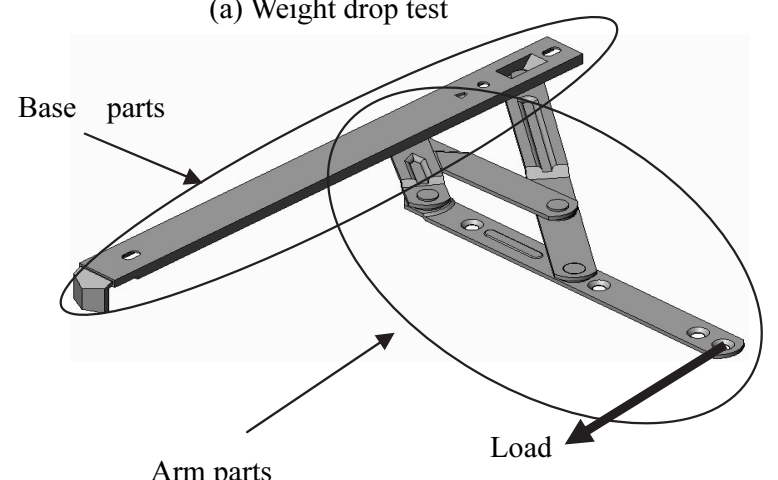

(b) Stopper part

図 20 ひずみエネルギー解析モデル

(Analytical strain energy model) 
図 20(b)に示すストッパー部品は，Base parts と Arm parts で構成され, Base parts にスライド部品があり， 風速 $3 \mathrm{~m} / \mathrm{s}$ 以下では摩擦力で動かない構造となって おり，摩擦力を超えると空があおられる。開閉する 力は静摩擦力と動摩擦力で異なり, 本研究では空が 開く時の動摩擦力を測定した。開き角度 0 から $10^{\circ}$ まで $0.5 \mathrm{rad} / \mathrm{s}$ のスピードを加え空を開き, 空の先端 に錘荷重を $1 \mathrm{~N}$ ステップで加え, 空が開き角度 $90^{\circ}$ まで移動した荷重を動摩擦力とした。その結果, 動 摩擦力は $16 \mathrm{~N}$ であった。

ストッパー部品は複数の部材で構成されており, Arm parts は4本のバーがピンで連結されたリンク構 造になっている。このストッパー部品のばね定数を 求めるため, 図 20(b)に示すようにストッパー部品の 先端に荷重を付加した。この際に得られた荷重と荷 重点変位の関係を図 21 に示す。 4 本のバーがリ

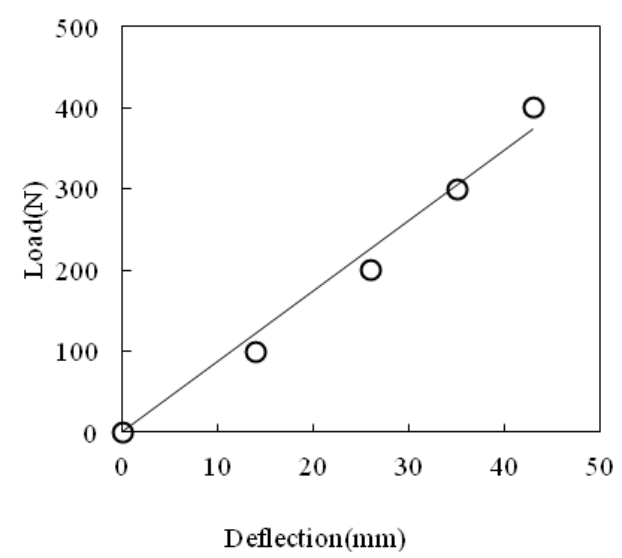

困 21 ストッパー部品荷重-変位図

(Stopper part load-deflection curve)

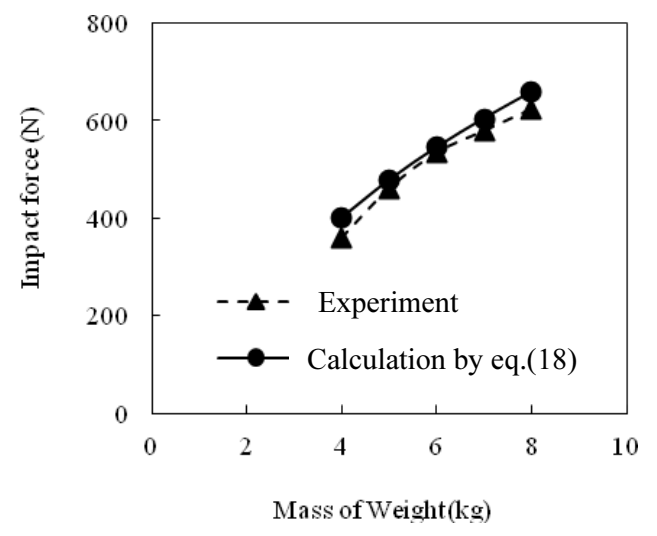

困 22 衝撃力-錘質量図

(Dynamic load-Mass of weight curve)
ンク構造になっているため, ピン等のガタつきによ るずれが見られるが, 直線近似し, 図.の直線の傾き から，ストッパー部品のばね定数 $k$ を求めた。

また，同じストッパー部品の平板部にひずみゲー ジを貼り付け，ひずみと荷重の関係を求めた。これ により，錘落下試験において，ストッパー部品に生 じるひずみから，ストッパー部品に作用する衝撃力 を測定できるようにした。

図 22 に, 式(18)で算出したストッパー部品に作用 する衝撃力と，錘落下試験により測定したストッパ 一部品に生じた衝撃力の比較を示す。両者は, よい 一致を示した。これにより，1 質量系単振動の運動 方程式の近似によって，エネルギーから衝撃力を評 価する方法の妥当性が確認され，ストッパー部品の 構造設計に必要な設計荷重が求められる。FEM 解析 等でこの衝撃力を荷重としてストッパー部品に作用 させることで，その強度計算ができる。

\section{6. 結 言}

開き空の安全性を確保するため, 側面風のエネル ギーを測定し, ベルヌイ式に基づいた風力エネルギ 一式の妥当性を確認し, エネルギーに関する考察か ら開き空のストッパー部品の弾性限度内での強度設 計に必要な衝撃力の評価について検討した。その結 果, 以下の結論を得た。

（1）側面風に対して, ベルヌイの定理から風力エネ ルギーを導出し，空の開き角度が $60^{\circ}$ から $75^{\circ}$ で作用する風力エネルギーが最大となること を実験および CFD 解析で明らかにした。実験 で得られた風力エネルギーを風速 $V$, 空幅 $W$, 空高さ $H$ の関数とする実験式として示し, 風 力エネルギーを簡単に評価できるようにした。

（2）前述した実験式に基づく風力エネルギーとべ ルヌイ理論式に基づいた風力エネルギーを比 較し, ベルヌイ理論式による風力エネルギーは 実験值による風力エネルギーより, 高目の評価 となることを示した。実験式が得られていない 場合は, ベルヌイ式で風力エネルギーを評価す ることで安全側の評価が行える。

（3）空の運動を 1 質量系単振動の運動方程式で近 
似し, 風力エネルギーとストッパー部品のばね 定数から, ストッパー部品に作用する衝撃力を 評価する方法を示した。ストッパー部品のばね 定数が既知であれば, 風力エネルギーから種々 の風速, 空寸法に対して, ストッパー部品に作 用する衝撃力を算出できる。この衝撃力を用い ることにより, FEM 解析等でのストッパー部 品の設計を可能にした。

\section{謝 辞}

試験実施にあたりサッシ協会の研究協力及び情報 提供していただいた(社)サッシ協会試験企画部会長 の山崎 健一氏, (財)建材試験センター和田 暢治氏, また論文投稿に対して多大なデータ提供をしていた だいた YKK AP(株)谷 芳郎氏，井上 浩文氏をはじ め本研究を実施にあたり，多くの方にご協力をいた だいた。ここに，心より感謝の意を表する次第であ る。

\section{参考文献}

1) 日本建築学会，「建築物荷重指針・同解説」，日 本建築学会(丸善), pp.321-434, (2004)

2) 荒川 治徳, 松本 洋一, 末松 茂正，「竪軸回転空 の耐衝撃性能に関する考察」, 日本建築学会大会学 術講演梗概集(関東), pp.195-196, (1988)

3)南 知宏, 黒木 勝一, 和田 暢治, 山崎 健一, 「外 開き空の煽り (衝撃) 試験方法の実験的研究その 1 おもりを使用したあおり試験方法の実験及び検討」, 日本建築学会大会学術講演梗概集（北海道）, pp.855-856, (2004)

4) 友清 衣利子, 竹内 崇, 前田 潤滋, 「風速の立ち 上がり時間に着目した突風の性状」，風工学会誌 vol.35, No.2(No.123), pp.118-123, (2010)

5) 桂 順治(代表), 「1990年12月11日千葉県に発生 した暴風災害の調查研究」, 文部省科学研究費

（No.02306029）突発災害調查研究成果報告, (1991) 6) 和田 暢治,「外開き空の煽り（衝撃）試験方法 の実験的研究」, 建材試験情報, 2008.5, pp.14-19, (2008)

7) 風工学研究所,「ビル風の基礎知識」, 鹿島出版
会, pp.73-86, (2005)

8) 風工学会, 「風工学ハンドブック」, 風工学会, pp.254-286, (2007)

9) 西江 学, 森 孝男, 「突風によりスイング空に生 じる衝撃力の評価」, M\&M2008 材料力学カンファレ ンス, $<$ OS 0917>, (2008)

10) 西江 学, 「突風による衝撃力を受けるスイング 空ストッパー部品の構造設計」, 日本機械学会2009 年度年次大会講演論文集, $<$ S0404-1-2>, ( 2009)

11) 西江 学, 森 孝男, 「開き空の突風による衝撃特 性評価」, 日本学術会議 第 60 回理論応用力学講演 会講演論文集, $<$ OS16-08 $>,(2011)$

12）西沢 繁毅，「評価・設計手法構築のための通風 環境の定量的な把握」，平成16年度国土交通省国土 技術研究会自由課題一般部門, (2005)

13）西江 学, 森 孝男，「突風を考慮した開き空ス卜 ッパー部品の衝撃特性評価」，日本機械学会2010年 度年次大会講演論文集, $<\mathrm{G} 0400-3-3>,(2010)$

14）茶谷 明義,「衝撃強度設計」, 日本材料学会2004 年衝撃部門委員会講演資料集, pp.119-123, (2004) 